\title{
Importance of Postoperative Atrial Fibrillation Development in Heart Surgery: Intra-Hospital Outcomes in Santa Catarina Tertiary Cardiology Center
}

\author{
Importância do Desenvolvimento de Fibrilação Atrial no Pós-Operatório \\ em Cirurgia Cardíaca: Desfechos Intra-Hospitalares em Centro Terciário de \\ Cardiologia Catarinense \\ Ricardo Pereira da Silva1', Larissa Freitas Nunes Goldoni1 ${ }^{1, *}$, Kárila Scarduelli Luciano, \\ Ana Carolina Gern Junqueira ${ }^{2}$, Ana Carolina Caldara Barreto ${ }^{2}$, Rafael De March Ronsoni ${ }^{1,2}$
}

ORCID IDS

Silva RP (iD https://orcid.org/0000-0002-8248-9609

Goldoni LFN (D) https://orcid.org/0000-0003-4340-0349

Luciano KS (D) https://orcid.org/0000-0002-5210-8414

\author{
Junqueira ACG (D) https://orcid.org/0000-0001-7250-0723 \\ Barreto ACC (D) https://orcid.org/0000-0002-3359-9940 \\ Ronsoni RDM (D) https://orcid.org/0000-0001-7135-9844
}

\begin{abstract}
Objective: To determine the incidence of postoperative atrial fibrillation (PAF) of cardiac surgery, its impact on morbimortality and duration of hospital stay in a tertiary cardiology center of the state of Santa Catarina, Brazil. Methods: Cohort study with 134 adult patients submitted to cardiac surgery. Results: the incidence was 32.8\%. After multivariate analysis, patients who did not receive beta-blockers were associated with PAF with a relative risk odds ratio (RR) 10.73 ( $p<0.001)$. The highest rate of cardiovascular events (cerebrovascular accident, mortality, and acute coronary syndrome) was $25 \%$ in the PAF group. $10 \%$ (RR 3.21; $p=0.035$ ) which, consequently, generated longer hospitalization time in these patients (19.1 vs. 12.5; $p=0.01$ ). Conclusion: the incidence of PAF was high, caused a significant increase in morbimortality and duration of hospital stay, and consolidated the role of beta-blocker therapy in its prevention, and may serve as a basis for future prevention policies.
\end{abstract}

KEYWORDS: Atrial fibrillation; Postoperative care; Morbidity.

\begin{abstract}
RESUMO
Objetivo: Determinar a incidência de fibrilação atrial no pós-operatório (FAPO) de cirurgia cardíaca, seu impacto sobre a morbimortalidade e o tempo de internação hospitalar em um centro terciário de cardiologia do estado de Santa Catarina, Brasil. Métodos: Estudo de coorte com 134 pacientes adultos submetidos à cirurgia cardíaca. Resultados: A incidência foi de 32,8\%. Após análise multivariada, os pacientes que não receberam betabloqueador estiveram associados à FAPO com razão de chances risco relativo (RR) 10,73 $(p<0,001)$. A maior taxa de eventos cardiovasculares (acidente vascular cerebral, mortalidade e síndrome coronariana aguda) foi de $25 \%$ no grupo FAPO vs. 10\% (RR 3,21; $p=0,035$ ) o que, consequentemente, gerou tempo de internação maior nesses pacientes $(19,1$ vs. 12,5; $p=0,01$ ). Conclusão: A incidência de FAPO foi elevada, ocasionou significativo aumento de morbimortalidade e tempo de internação hospitalar e consolidou o papel da terapia betabloqueadora na sua prevenção, podendo servir como base a futuras políticas de prevenção dessa intercorrência.
\end{abstract}

PALAVRAS-CHAVE: Fibrilação atrial; Cuidados pós-operatórios; Morbidade.

1. Hospital Regional Hans Dieter Schmidt - Serviço de Cardiologia - Joinville/SC- Brazil.

2.Universidade da Região de Joinville - Departamento de Medicina - Joinville/SC - Brazil.

*Correspondence author: larissanunes_@hotmail.com

Received: 13 Jan 2019 | Accepted: 3 Jul 2019

Section Editor: J Tarcisio Medeiros de Vasconcelos 


\section{INTRODUCTION}

Postoperative atrial fibrillation (PAF) is the most prevalent complication after cardiac surger ${ }^{1,2}$. In the postoperative period (PP) of cardiac surgery, the incidence of PAF varies between 25 and 62\%, depending on the type of surgery ${ }^{2,3}$. PAF predisposes the patient to a higher incidence of thromboembolic events, hemodynamic instability, and increases the chance of a cerebrovascular accident (CVA) by 2.5 to 4.5 times $^{4,5}$. The duration of hospital stay of patients with PAF is also longer, causing higher costs to the health ${ }^{6}$.

The peak incidence of this arrhythmia is on the second to fourth postoperative day, and studies indicate that its risk may be reduced with the administration of specific perioperative drugs ${ }^{7,8}$. The identification of patients at high risk for developing PAF may be of great value for early intervention and preventive measures to reduce morbimortality ${ }^{5}$. Although some factors, such as advanced age and underlying comorbidities, are already established for the development of this tachyarrhythmia, the pathophysiological mechanisms are not yet fully elucidated, but activation of the sympathetic nervous system and the inflammatory process caused by surgery are the most accepted ${ }^{1,9-11}$.

Although these tachyarrhythmias are considered transient and benign, in specific patient clinical profiles, they may have different outcomes ${ }^{1,4}$. Despite efforts to reduce its occurrence, the improvement of the surgical technique and anesthesia methods did not cause a significant reduction in this complication, and its prevention is still a challenge ${ }^{3,4}$.

This study aims to evaluate the intra-hospital outcomes associated with the development of PAF. Besides, to determine the incidence and its associated factors in a tertiary cardiology center of Santa Catarina.

\section{METHODS}

A retrospective historical cohort study of 147 adult patients (age $\geq 18$ years) who submitted to cardiac surgery (with or without extracorporeal circulation due to ischemic heart disease, and/or valve associated or not, another procedure) in 2015 at the Hans Dieter Schmidt Regional Hospital, in Joinville, State of Santa Catarina. Of these, 13 patients who were diagnosed with persistent or permanent, paroxysmal atrial fibrillation (AF) were excluded, leaving 135 patients for analysis. The outcomes studied were the occurrence of PAF, clinical [mortality, duration of stay, cardiovascular events - acute coronary syndrome (ACS), and CVA] and factors associated with the development of PAF.

According to the institutional protocol, all patients were submitted to continuous cardiac monitoring for 48 hours in an intensive care setting and daily electrocardiographic examinations until hospital discharge. Additional electrocardiograms were performed for cardiovascular symptoms and/or asymptomatic tachycardia.

AF was defined as supraventricular arrhythmia whose electrocardiographic tracing showed "f" waves of variable morphology and amplitude, with irregular ventricular rhythm. Episodes of AF lasting at least 30 seconds or requiring treatment due to symptomatology or hemodynamic instability were considered for work.

Echocardiographic parameters of left ventricular ejection fraction (LVEF) and left atrial diameter (LA) were collected by the most recent exam found in the records, which includes both transesophageal (TEE) and transthoracic (TTE) examinations. The ejection fraction was calculated using the Teicholz or Simpson methods, according to the presence of segmental dysfunction. Atrial diameters were assessed using the $\mathrm{M}$ mode.

The medical records were reviewed in order to record the clinical information necessary to complete the clinical protocol. These clinical diagnoses were defined according to the previous publications ${ }^{12}$.

The strength of association of each factor for PAF was measured by relative risk (RR) estimates with $95 \%$ confidence intervals (95\% CI). Data analysis was performed with the aid of the SPSS version 8.0 program. In multivariate analysis, binary logistic regression and the odds ratio (OR) were used as an association measure. In the model construction process, the importance of each component was verified by the likelihood ratio test. A value of $-2 \log$ likelihood was used (deviance), measured to determine how well the model fits the data. Interval estimates were calculated with $95 \%$ CI. All variables with $\mathrm{p}<0.25$ (univariate analysis) were candidates to enter the model, according to the methodology of Hosmer and Lemeshow ${ }^{13}$. Only variables with $\mathrm{p}<0.05$ remained in the model.

The hospital's research ethics committee approved the study protocol (no 1.779.036). 


\section{RESULTS}

Of the 134 patients submitted to cardiac surgery, $32.8 \%$ developed PAF. This incidence is related to postoperative time and showed that about $80 \%$ occurred from the second to the fourth postoperative day, with a peak on the third day (40\%).

Regarding the clinical profile of the patients, the only ones that showed significance in bivariate analysis were over 70 years $(\mathrm{p}=0.003)$ and non-use of betablocker therapy in the perioperative period $(\mathrm{p}<0.001)$ (Table 1).
In Table 2, after multivariate analysis, the non-use of beta-blockers therapy remained statistically significant with an OR of 10.73 (95\% CI 3.47-3.12; p <0.001).

The overall mortality in the sample was $17 \%$, and there was a tendency for higher mortality in the PAF patients (0.19 \pm 0.39 vs. $0.07 \pm 0.25 ; p>0.05)$ (Fig. 1$)$, but when grouped into composite outcomes, cardiovascular events (CVA, mortality, and ACS) were observed with an incidence of 25\% in the group that developed PAF. 10\% [OR 3.21; 95\% CI 1.08-11.58; $\mathrm{p}=0.035$ ] (Table 3).

The duration of stay was longer in patients with this complication $(19.11 \pm 15.87$ vs. $12.58 \pm 12, \mathrm{p}=0.01)$ (Fig. 2).

Table 1. Bivariate analysis of categorical variables and postoperative atrial fibrillation (PAF).

\begin{tabular}{|c|c|c|c|c|}
\hline Period & Variable & $\begin{array}{c}\text { PAF } \\
\mathrm{n}=44(\%)\end{array}$ & $\begin{array}{c}\text { No PAF } \\
\mathrm{n}=90(\%)\end{array}$ & p-value \\
\hline \multirow[t]{14}{*}{ Preoperative } & Male & $28(63.6)$ & $56(62.2)$ & 0.874 \\
\hline & Age over 70 years & $14(31.8)$ & $10(11.1)$ & $0.003^{+}$ \\
\hline & Chronic obstructive pulmonary disease & $19(43.2)$ & $29(32.2)$ & 0.214 \\
\hline & Creatinine clearance $<50 \mathrm{mg} / \mathrm{dL}$ & $05(11.4)$ & $04(4.40)$ & $0.154^{*}$ \\
\hline & Extracardiac Arteriosclerosis & $08(18.2)$ & $19(21.1)$ & 0.691 \\
\hline & Previous heart surgery & $01(2.30)$ & $05(5.60)$ & $0.663 *$ \\
\hline & Endocarditis & $03(6.80)$ & $03(3.30)$ & $0.394 *$ \\
\hline & Preoperative critical state & $06(13.6)$ & $07(7.80)$ & $0.353^{*}$ \\
\hline & Rest Angina & $02(4.50)$ & $06(6.70)$ & $1.000 *$ \\
\hline & Ejection fraction $<50 \%$ & $15(32.6)$ & $29(33.0)$ & 0.968 \\
\hline & Recent acute heart attack & $10(22.7)$ & $29(32.2)$ & 0.256 \\
\hline & Pulmonary arterial hypertension & $06(13.6)$ & $04(4.40)$ & $0.080 *$ \\
\hline & Emergency surgery & $03(6.80)$ & $04(4.40)$ & $0.683^{*}$ \\
\hline & Major Mitral Disease & $05(11.4)$ & $10(11.1)$ & $1.000 *$ \\
\hline \multirow[t]{3}{*}{ Intraoperative } & Myocardial revascularization surgery & $31(70.5)$ & $69(76.7)$ & 0.438 \\
\hline & Valve surgery & $11(25.0)$ & $19(18.9)$ & 0.414 \\
\hline & Combined surgery & $02(4.50)$ & $04(4.40)$ & $1.000 *$ \\
\hline \multirow[t]{4}{*}{ Postoperative (PO) } & Water balance $>1,500 \mathrm{~mL}$ within 48 hours PO & $33(75.0)$ & $54(60.0)$ & 0.087 \\
\hline & Use of non-steroidal anti-inflammatory drugs & $02(4.50)$ & $02(2.20)$ & $0.59 *$ \\
\hline & No pre and PO angiotensin-converting enzyme inhibitors & $27(61.4)$ & $44(48.9)$ & 0.174 \\
\hline & No beta-blockers in pre and PO & $40(90.9)$ & $46(51.1)$ & $0.000^{+}$ \\
\hline
\end{tabular}

Statistical method employed: chi-square test and, when necessary, Fischer’s exact test *. ${ }^{\dagger} p<0.05$ considered statistically significant.

Table 2. Variables associated with postoperative atrial fibrillation (PAF) in logistic regression (univariate and multivariate analysis with and without the PAF outcome).

\begin{tabular}{ccccc}
\hline Variable & Gross OR $(95 \% \mathrm{Cl})$ & p-value & Adjusted OR $(95 \% \mathrm{Cl})$ & p-value \\
\hline No beta-blockers pre and PO & $8.445(2.608-27.346)$ & 0.000 & $10.735(3.479-33.125)$ & $0.000^{\dagger}$ \\
Age $>$ 70 years & $2.127(0.775-5.837)$ & 0.115 & - & - \\
\hline
\end{tabular}

Statistical method employed: univariate and multivariate binary logistic regression; 95\% Cl = 95\% confidence interval; PO = postoperative; RC = odds ratio. $\uparrow$ variables that remained in the final model $p<0.05$. 


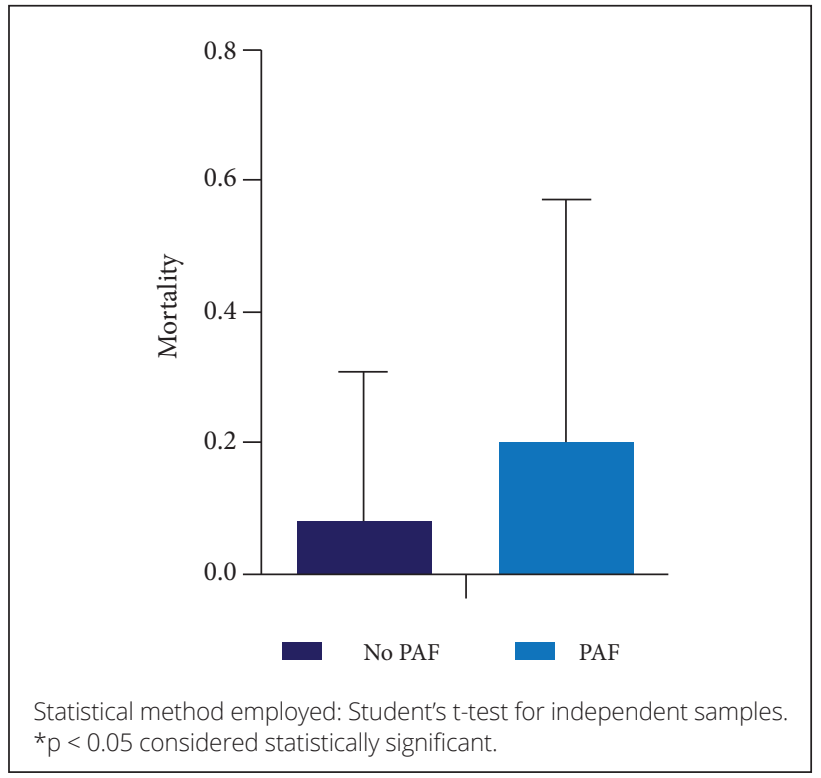

Figure 1. Mortality with and without postoperative atrial fibrillation (PAF).

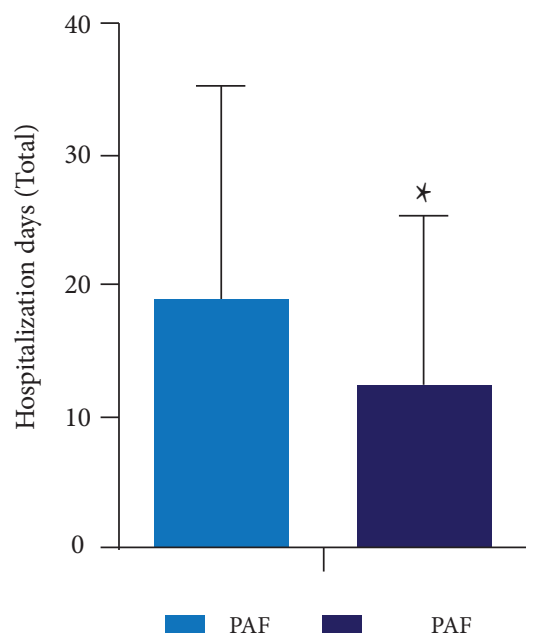

Statistical method employed: Student's t-test for independent samples. ${ }^{*} p<0.05$ considered statistically significant.

Figure 2. Days of total hospitalization with and without postoperative atrial fibrillation (PAF).

Table 3. Analysis of cardiovascular events.

\begin{tabular}{ccccc}
\hline Variable & PAF & No PAF & Adjusted OR & p-value \\
& $\mathrm{n}=\mathbf{4 4}(\%)$ & $\mathrm{n}=90(\%)$ & (95) & $0.035^{\dagger}$ \\
\hline Cardiovascular events & $11(25)$ & $9(10)$ & $3.21(1.08-11.58)$ & \\
\hline
\end{tabular}

PAF = postoperative atrial fibrillation; 95\% Cl = 95\% confidence interval; RC = odds ratio. Statistical method employed: Chi-square test and, when necessary, Fischer's exact test; † $p<0.05$ considered statistically significant.

\section{DISCUSSION}

Despite the evolution of surgical techniques and $\mathrm{PO}$ management, PAF remains a very common complication ${ }^{14-17}$. An incidence of $32.8 \%$ was found, similar to the average reported in other published studies ${ }^{18-20}$.It is worth mentioning that continuous monitoring was used during intensive care and after intermittent electrocardiogram, which may have underestimated asymptomatic PAF. In some studies where continuous monitoring was used, rates reached ${ }^{44}$ to $64 \%$; however, this modality is adopted in a minority of published works ${ }^{21,22}$. Therefore, the data show a high incidence, stimulating the search for factors that contribute to PAF, thus being one of the objectives of this study.

The chronology was consistent with previously published data, in which most episodes occur until the fourth day of the postoperative period; in this study occurred in $80 \%$ of cases $^{23}$.

Before mentioning the factors associated with PAF, it is crucial to establish the multifactorial mechanisms associated with the development of arrhythmia ${ }^{24}$. Among them, perhaps the most easily approached by prophylactic measures is an autonomic imbalance, caused mainly by sympathetic hyperstimulation through the use of betablockers medications. In this study, it was indeed found that the non-use of this drug class had a more significant impact on the occurrence of arrhythmia. After multivariate analysis, a CR of 10.73 was obtained, reflecting the fundamental importance of the sympathetic nervous system block in this clinical context. Moreover, this is confirmed in the literature by a meta-analysis of 4.074 patients who found $\mathrm{RR}$ of 0.35 (95\% CI 0.26-0.49) associated with this protective finding with therapy ${ }^{25}$. Importantly, the worst clinical scenario described would be the non-use of medication in pre and $\mathrm{PO}^{25,26}$. These results solidify this factor as fully modifiable through medical awareness of its use during this critical period. Also, they could be used as guidance or indicators for policies to prevent this complication.

Older age 70 years is an essential predictor of PAF in the literature. Mathew et al. ${ }^{27}$ documented that, for each decade, there is a $75 \%$ increase in the chance 
of arrhythmic occurrence. The researchers concluded that based on age alone, anyone over the age of 70 is considered at high risk for developing $\mathrm{PAF}^{27}$. In this study, there was an association in bivariate analysis, but after logistic regression age did not remain significantly statistical, most likely related to sampling size.

Regarding clinical outcomes, total mortality is associated with the development of PAF. When using the Society of Thoracic Surgeons (STS) database, reaching 49.264 patients, the group that developed PAF has twice the chance of mortality (RR 2.04, $\mathrm{p}<0.001)^{28}$. Confirming STS data, Almassi et al. ${ }^{29}$, in an analysis of 3.855 patients submitted to cardiac surgery, found intra-hospital mortality of $6 \%$ in the group of patients with PAF vs. $3 \%$ in the group without arrhythmia. In this study, there was a tendency to increase with PAF, but without statistical significance, which could be explained by the association of sample size (reduced) and incidence of mortality (increased) when compared to studies already published.

PAF is associated with an increased incidence of major morbid events ${ }^{29}$, such as increased thromboembolic risk $^{30}$ and myocardial ischemia, and this is particularly pronounced in increased CVA, as analyzed in the STS database between 2004 and 2005 of myocardial revascularization surgeries, where CVA prevalence increased ( 4 vs. $1.9 \%, p=0.002)^{6}$. In this study, they grouped into a combined outcome of CVA and ACS mortality and reached a CR of $3.2(\mathrm{p}<0.05)$, which demonstrates the morbid potential of PAF.

Given the data found of higher morbidity associated with PAF, it is understandable to expect an increase in the duration of stay in days, as observed in our study $(19.11 \pm 15.87$ vs. $12.58 \pm 12 ; \mathrm{p}=0.01)$. Data from a Brazilian group showed similar results of a more extended hospital stay in days $(16.9 \pm 12.3 \text { vs. } 9.2 \pm 4, \mathrm{p}<0.001)^{31}$.

Importantly, as the data source is from a clinical database, we have an estimation of the "real world" and data from the Brazilian public system. This consolidates future PAF prevention policies to minimize clinical and financial effects on health systems.

\section{AUTHORS' CONTRIBUTION}

Conceptualization, Silva R and Ronsoni R and Goldoni L; Methodology, Silva R and Ronsoni R and Scarduelli K, Investigation, Barreto ACC and Junqueira ACG; Writing - first version, Silva R and Barreto ACC and Junqueira ACG; Writing - Revision and Editing, Goldoni L and Ronsoni R; Supervision Ronsoni R and Scarduelli K.

\section{REFERENCES}

1. Shen J, Lall S, Zheng V, Buckley P, Damiano RJ, Schuessler RB. The persistent problem of new onset postoperative atrial fibrillation: a single institution experience over two decades. The J Thorac Cardiovasc Surgery. 2011;141(2):55970. https://doi.org/10.1016/j.jtcvs.2010.03.011

2. Villareal RP, Hariharam R, Liu BC, Kar B, Lee W, Elayda M, et al. Postoperative atrial fibrillation and mortality after coronary artery bypass surgery. J Am Coll Cardiol. 2004;43(5):742-8. https://doi.org/10.1016/j.jacc.2003.11.023

3. Ommen SR, Odell JA, Marshall S. Stanton. Atrial arrhythmias after cardiothoracic surgery. N EnglJ Med. 1997;336(20):142934. https://doi.org/10.1056/NEJM199705153362006

4. Mariscalco G, Klersy C, Zanobini M, Banach M, Ferrarese $\mathrm{S}$, Borsani $\mathrm{P}$, et al. Atrial fibrillation after isolates coronary surgery affects late survival.Circulation. 2018;118(16):16128. https://doi.org/ 10.1161/CIRCULATIONAHA.108.777789

5. Geovanini GR, Alves RJ, Brito G de, Miguel GAS, Glauser VA, Nakiri K. Fibrilação atrial no pós-operatório de cirurgia cardíaca: quem deve receber quimioprofilaxia? Arq Bras
Cardiol. 2009;92(4):326-30. https://doi.org/10.1590/50066$782 \times 2009000400013$

6. Steinberg BA, Zhao $Y$, He X, Hernandez AF, Fullerton DA, Thomas $\mathrm{KL}$, et al. Management of postoperative atrial fibrillation and subsequent outcomes in contemporary patients undergoing cardiac surgery: insights from the Society of Thoracic Surgeons CAPS-Care Atrial Fibrillation Registry. Clin Cardiol. 2014;37(1):7-13. https://doi. org/10.1002/clc.22230

7. Mahoney EM, Thompson TD, Veledar E, Williams J, Weintraub WS. Cost-effectiveness of targeting patients undergoing cardiac surgery for therapy with intravenous amiodarone to prevent atrial fibrillation. J Am Coll Cardiol. 2002;40(4):73745. https://doi.org/10.1016/S0735-1097(02)02003-X

8. Silva RG da, Lima GG de, Guerra N, Bigolin AV, Petersen LC. Proposta de escore de risco para predição de fibrilação atrial após cirurgia cardíaca. Rev Bras Cir Cardiovasc. 2010;25(2):18319. https://doi.org/10.1590/S0102-76382010000200009 
9. Creswell LL, Schuessler RB, Rosenbloom M, Cox JL. Hazards of postoperative atrial arrhythmias. Ann Thoruc Surg. 1993;56(3):539-49. https://doi.org/10.1016/00034975(93)90894-n

10. Angelini P, Feldman Ml, Lufschanowski R, Leachman RD Cardiac arrhythmias during and after heart surgery: diagnosis and management. Prog Cardiovasc Dis. 1974;16(5):469-95. https://doi.org/10.1016/0033-0620(74)90007-3

11. Albahrani MJ, Swaminathan M, Phillips-Bute B, Smith PK, Newman MF, Mathew JP, et al. Postcardiac surgery complications: association of acute renal dysfunction and atrial fibrillation. Anesth Analg. 2003;96(3):637-43. https:// doi.org/10.1213/01.ane.0000047886.81598.2c

12. Lip GY, Nieuwlaat R, Pisters R, Lane DA, Crijns HJ. Refining clinical risk stratification for predicting stroke and thromboembolism in atrial fibrillation using a novel risk factor-based approach: the Euro Heart Survey on atrial fibrillation. Chest. 2010;137(2):263-72. https://doi.org/ 10.1378/chest.09-1584

13. Hosmer DW, Lemeshow S. Applied logistic regression. New York: John Wiley; 1989.

14. Mathew JP, Parks R, Savino JS, Friedman AS, Koch C, Mangano DT, et al. Atrial fibrillation following coronary artery bypass graft surgery: predictors, outcomes, and resource utilization. MultiCenter Study of Perioperative Ischemia Research Group. JAMA. 276(4):300-6. https://doi. org/10.1001/jama.1996.03540040044031

15. Echahidi N, Mohty D, Pibarot P, Després J-P, O'Hara G, Champagne J, et al. Obesity and metabolic syndrome are independent risk factors for atrial fibrillation after coronary artery bypass graft surgery. Circulation. 2007;116(11 Suppl):1213-9. https://doi.org/10.1161/ CIRCULATIONAHA.106.681304

16. Osranek M, Fatema K, Qaddoura F, Al-Saileek A, Barnes ME, Bailey KR, et al. Left atrial volume predicts the risk of atrial fibrillation after cardiac surgery: a prospective study. J Am Coll Cardiol. 2006;48(4):779-86. https://doi.org/10.1016/j. jacc.2006.03.054

17. Sabzi F, Zokaei AH, Moloudi AR. Predictors of atrial fibrillation following coronary artery bypass grafting. Clin Med Insights Cardiol. 2011;5:67-75. https://doi.org/10.4137\%2FCMC. S7170

18. Echahidi N, Pibarot P, O'Hara G, Mathieu P. Mechanisms, prevention, and treatment of atrial fibrillation after cardiac surgery. J Am Coll Cardiol. 2008;51(8):793-801. https://doi. org/10.1016/j.jacc.2007.10.043.

19. Maisel WH, Rawn JD, Stevenson WG. Atrial fibrillation after cardiac surgery. Ann Intern Med. 2001;135(12):1061. https:// doi.org/10.7326/0003-4819-135-12-200112180-00010

20. Nazeri A, Razavi M, Elayda MA, Lee V-V, Massumi A, Wilson $\mathrm{JM}$, et al. Race/ethnicity and the incidence of new-onset atrial fibrillation after isolated coronary artery bypass surgery. Hear Rhythm. 2010;7(10):1458-63. https://doi. org/10.1016/j.hrthm.2010.06.037
21. Siebert J. Atrial fibrillation after coronary artery bypass grafting without cardiopulmonary bypass. Eur J CardioThoracic Surg. 2000;17(5):520-3. https://doi.org/10.1016/ S1010-7940(00)00368-7

22. Helgadottir S, Sigurdsson MI, Ingvarsdottir IL, Amar DO, Gudbjartsson T. Atrial fibrillation following cardiac surgery: risk analysis and long-term survival. J Cardiothorac Surg. 2012;7(1):87-93. https://doi.org/10.1186/1749-8090-7-87

23. Kannel WB, Abbott RD, Savage DD, McNamara PM. Epidemiologic features of chronic atrial fibrillation. N Engl J Med. 1982;306(17):1018-22. https://doi.org/10.1056/ NEJM198204293061703

24. Yadava M, Hughey AB, Crawford TC. Postoperative atrial fibrillation: incidence, mechanisms, and clinical correlates. Cardiol Clin. 2014;32(4):627-36. https://doi.org/10.1016/j. ccl.2014.07.002

25. Crystal E, Garfinkle MS, Connolly SS, Ginger TT, Sleik K, Yusuf SS. Interventions for preventing post-operative atrial fibrillation in patients undergoing heart surgery. Cochrane Database Syst Rev. 2004;18(4):CD003611. https://doi. org/10.1002/14651858.CD003611.pub2

26. Andrews TC, Reimold SC, Berlin JA, Antman EM. Prevention of supraventricular arrhythmias after coronary artery bypass surgery. A meta-analysis of randomized control trials. Circulation. 1991;84(5 Suppl):III236-44.

27. Mathew JP, Fontes ML, Tudor IC, et al. A multicenter risk index for atrial fibrillation after cardiac surgery. JAMA. 2004;291(14):1720-9. https://doi.org/10.1001/ jama.291.14.1720

28. LaPar DJ, Speir AM, Crosby IK, et al. Postoperative atrial fibrillation significantly increases mortality, hospital readmission, and hospital costs. Ann Thorac Surg. 2014;98(2):527-33; discussion 533. https://doi. org/10.1016/j.athoracsur.2014.03.039

29. Almassi GH, Schowalter T, Nicolosi AC, Aggarwal A, Moritz TE, Henderson WG, et al. Atrial fibrillation after cardiac surgery: a major morbid event? Ann Surg. 1997;226(4):501-11. https://doi.org/10.1097/00000658-199710000-00011

30. Fuller JA, Adams GG, Buxton B. Atrial fibrillation after coronary artery bypass grafting. Is it a disorder of the elderly? J Thorac Cardiovasc Surg. 1989;97(6):821-5.

31. Silva RG, Lima GG, Laranjeira A, Costa AR, Pereira E, Rodrigues R. Fatores de risco e morbimortalidade associados à fibrilação atrial no pós-operatório de cirurgia cardíaca. Arq Bras Cardiol. 2004;83:99-104. https://doi.org/10.1590/ S0066-782X2004001400002 